36. Soluene 100, Packard Instrument Co., Downer's Grove, Ill

37. This research was supported by grants from the National Heart and Lung Institute, National Institutes of Health (HL16137); New York Heart Association grant-in-aid; and United States-Italy Cooperative Science Program (C.N.R., Rome, No. 73.00681.65)

38. Dr. E. M. Scarpelli is a recipient of a Career Development Award from the National Heart and Lung Institute of the National Institutes of Health.

39. Requests for reprints should be addressed to: E. M. Scarpelli, M.D., Department of Pediatrics, Albert Einstein College of Medicine, 1300 Morris Park Ave., Bronx, N.Y. 10461 (USA).

40. Accepted for publication January 2, 1975.
Alveolar hyaline membranes cytidine

fetus

lecithin lung neonate phosphorylcholine cytidyltransferase respiratory distress syndrome

\title{
The Enzymes of Lecithin Biosynthesis in Human Neonatal Lungs. IV. Phosphorylcholine Cytidyltransferase
}

\author{
MICHAEL L. THOM AND RICHARD D. ZACHMAN (3 7) \\ Department of Pediatrics of the University of Wisconsin and The Wisconsin Perinatal Center, \\ Madison, Wisconsin, USA
}

\section{Extract}

Phosphorylcholine cytidyltransferase, the enzyme which catalyzes the transfer of phosphorylcholine to cytidine $5^{\prime}$-triphosphate to form CDP-choline, was studied for the first time in human neonatal lung. The assay of product synthesis was linear for $10-20 \mathrm{~min}$ and up to $12 \mathrm{mg}$ protein. The $\mathrm{pH}$ optimum was $6-6.5$. The $\mathrm{K}_{\mathrm{m}}$ of CTP was $2.0 \times 10^{-3} \mathrm{M}$, and the $\mathrm{K}_{\mathrm{m}}$ of phosphorylcholine was $0.25 \times 10^{-3} \mathrm{M}$. The true $\mathrm{V}_{\max }$ was $10 \mathrm{nmol}$ CDP-choline $/ \mathrm{mg}$ protein $/ 10 \mathrm{~min}$. The enzyme was stable under frozen conditions. Oxygen had no apparent affect on enzyme activity.

\section{Speculation}

In some tissues, phosphorylcholine cytidyltransferase is possibly the site for a feedback control mechanism of lecithin synthesis. Since there is a relationship between pulmonary lecithin synthesis and neonatal respiratory distress syndrome, purification and characterization of phosphorylcholine cytidyltransferase from human neonatal lung may be of significance.

Lecithin is a major component of lung alveolar surfactant $(8,20,22,24)$, and a relationship between lung surfactant and neonatal respiratory distress has been established $(1,4,9,10$, $12,15)$. Lung surfactant activity accompanies increased lecithin biosynthesis in the developing fetus of several species $(13,14,28)$, and lung extracts from infants dying of respiratory distress with alveolar hyaline membranes have abnormal surface active properties $(15,20)$. De novo lecithin synthesis in lung tissue of experimental animals occurs by at least two pathways (1) the formation of phosphorylcholine and its transfer from cytidine diphosphorylcholine (CDPcholine) to 1,2-diacyl-sn-glycerol (D- $\alpha, \beta$-diglyceride) $(3,5,17$, 27 ), and (2) the trimethylation of ethanolamine phosphoglyceride $(7,14,19)$.
Lecithin biosynthesis in human neonatal lung is being investigated indirectly by assaying the enzyme activities of the pathways. Preliminary characterization of phosphorylcholine cytidyltransferase (EC 2.7.7.15), the enzyme responsible for the second step in the CDP-choline pathway, is reported here. Although briefly studied in the rat (26), this enzyme has not been studied previously in the human lung.

\section{EXPERIMENTAL PROCEDURE}

CTP (32) and $\mathrm{MgCl}_{2}$ (33) were used without further purification to prepare a $\mathrm{MgCTP}$ solution at $30 \mathrm{mM}$ in both magnesium and CTP. The pH was adjusted to 7.0 by dropwise addition of $\mathrm{NaOH}$.

Radioactive 1,2-[ $\left.{ }^{14} \mathrm{C}\right]$ phosphorylcholine with a specific activity of $117 \mathrm{mCi} / \mathrm{mM}$ (34) was diluted to $20 \mu \mathrm{Ci} / \mathrm{ml}$ and $1.0-\mathrm{ml}$ aliquots were stored in a freezer at $-12^{\circ}$ until use. Unlabeled phosphorylcholine $(100 \mathrm{mM})$ in phosphate buffer $(0.067 \mathrm{M}, \mathrm{pH} 7.4)$ was also frozen until the reaction solution was prepared by mixing equal volumes of unlabeled and radioactive phosphorylcholine, producing a solution $50 \mathrm{mM}$ in phosphorylcholine with a specific activity of $10 \mu \mathrm{Ci} / \mathrm{ml}$.

Lung tissue was obtained at autopsy from neonates $1-7 \mathrm{hr}$ after death and immediately frozen at $-12^{\circ}$. Just before use, a piece of lung was weighed and homogenized in a glass mortar with a motor-driven Teflon pestle in 3 volumes of phosphate buffer $(0.067 \mathrm{M}, \mathrm{pH} 7.4)$. Fresh homogenate was prepared for each assay unless otherwise indicated.

The assay used was similar to that described (6) with some modifications. The standard assay mixture contained $3-10 \mathrm{mg}$ tissue homogenate protein, Tris-succinate $(8 \mathrm{mM}, \mathrm{pH} 7.5)$, and $1,2-\left[{ }^{14} \mathrm{C}\right]$ phosphorylcholine $(1 \mu \mathrm{Ci}, 5 \mathrm{mM})$. This mixture was preincubated for $5 \mathrm{~min}$ at $37^{\sim}$, then the reaction was started by the addition of MgCTP to a final concentration of $6 \mathrm{mM}$. The final volume of the incubation mixture was $1.0 \mathrm{ml}$. The samples were incubated for $10 \mathrm{~min}$ at $37^{\circ}$, and the reaction was stopped by placing the tubes in a boiling water bath for 5 
min. Blanks containing homogenate and buffer were boiled for 5 min and then treated as for the other samples. The boiled reaction mixtures were cooled in ice, then after centrifuging for $5 \mathrm{~min}$ at $2,500 \times \mathrm{g}, 0.50 \mathrm{ml}$ supernatant was withdrawn and delivered to a clean centrifuge tube. The reaction product, radioactive CDP-choline, was separated from substrate $1,2-\left[{ }^{14} \mathrm{C}\right]$ phosphorylcholine by adsorption of the former on Norit A charcoal (32). The charcoal was washed four times with unlabeled phosphorylcholine to insure removal of unreacted radioactive phosphorylcholine, and the pellet from the final washing was dried for $1 \mathrm{hr}$ at $60^{\circ}$. After cooling, 1.0 $\mathrm{ml}$ formic acid was added, and the pellet was resuspended, mixed, and then centrifuged $(5 \mathrm{~min}, 2,500 \times \mathrm{g})$. One-half milliliter of the supernatant, which contained $1,2-\left[{ }^{14} \mathrm{C}\right] \mathrm{CDP}$ choline (6) was delivered to $15 \mathrm{ml}$ scintillation solution $(3.3 \mathrm{~g}$ 3,5-diphenyloxazole in $400 \mathrm{ml}$ toluene plus $200 \mathrm{ml}$ ethylene glycol monomethyl ether). The samples were counted in a Beckman CMP-100 room temperature liquid scintillation system. Variable quenching was accounted for by the external standard channels ratio method.

Of the charcoal, $92 \%$ was retained through the washings and supernatant withdrawals, and the results were corrected for the $8 \%$ loss of product. Negligible amounts $(<1 \%)$ of radioactivity as lecithin were isolated by thin layer chromatography even after $90 \mathrm{~min}$ of incubation, so significant product loss through further reactions did not occur. Protein determinations were done by the biuret method. After correcting for counting efficiency, $1,2-\left[{ }^{14} \mathrm{C}\right]$ phosphorylcholine, and using the known specific activity of the $1,2-\left[{ }^{14} \mathrm{C}\right]$ phosphorylcholine, the results were expressed in nanomoles of CDPcholine per milligram of protein per 10-min incubation. Duplicates were within $2-5 \%$ of one another.

A blank was always run with each assay since the blank value varied directly with the concentration of substrate and inversely with the amount of protein present in the assay mixture. In addition, the enzyme levels stated are $10 \%$ below their actual value since some $10 \%$ of the product $(1,2-$ $\left[{ }^{14} \mathrm{C}\right] \mathrm{CDP}$-choline) was bound to heat-denatured protein at the levels of protein used in routine assays. Relative velocities and $K_{m}$ values are accurate, however, since in the kinetic constant experiments, a large amount of homogenate from the same tissue was prepared and frozen in aliquots suitable for each day's experiment, a process which took 4 days. The enzymatic activity of the homogenate was not expected to change in that period and the percentage product loss because of absorption onto homogenate protein was constant for each experiment.

\section{RESULTS}

Product synthesis was linearly dependent upon the amount of tissue homogenate protein added to the reaction mixture up to $12 \mathrm{mg}$ protein. Activity was linear for $10-20 \mathrm{~min}$, but slowed slightly at incubation times above $20 \mathrm{~min}$. The $\mathrm{pH}$ optimum was in the region of 6.5 (Fig. 1).

Activity was maximal near $50^{\circ}$ (Table 1). The effect of frozen storage was determined by homogenizing and assaying a portion of a lung sample 1-hr postmortem and later. This homogenate was frozen and assayed again at 6 and 13 days. Another portion of the 1-hr postmortem tissue was frozen and also assayed at 6 and 13 days, and a fresh homogenate was prepared each time. A 7-hr postmortem sample of the same tissue was obtained, frozen, and also assayed at 6 and 13 days using fresh homogenate each time. The data in Table 1 show that freezing homogenate or whole tissue for 13 days did not effect activity, nor was there any difference in activity from the tissue removed 1 or $7 \mathrm{hr}$ postmortem. Tissue has now been frozen for over 6 weeks without loss of activity.

Oxygen had no apparent effect on enzyme activity during the 10-min assay time period (Table 1). Whole homogenate

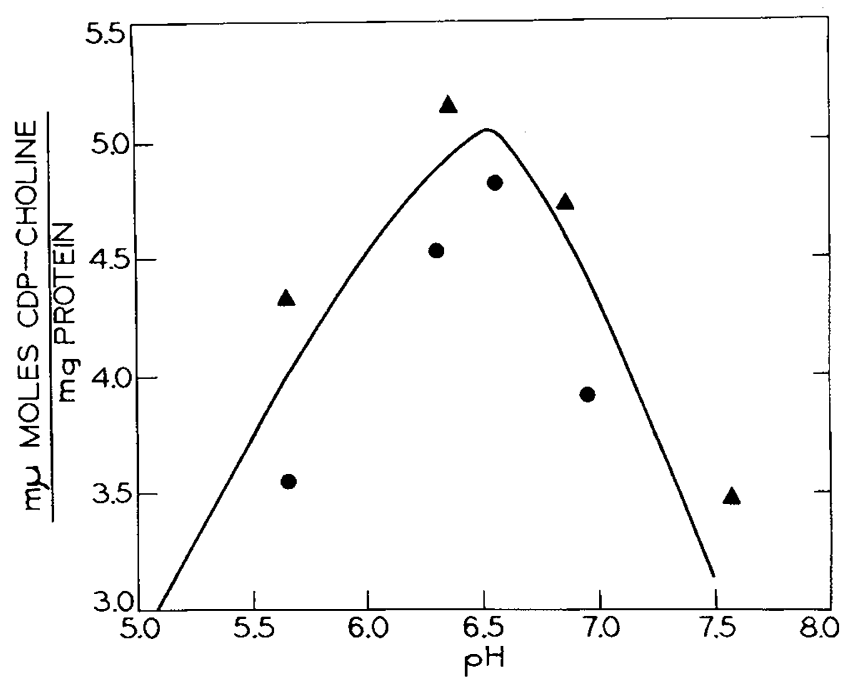

Fig. 1. Effect of $\mathrm{pH}$ on enzyme activity. Results of two separate experiments, carried out at varying $\mathrm{pH}$ are presented. Tris-succinate buffers were prepared at $\mathrm{pH}$ values of $5.0,6.0,7.0$, and 8.0. The actual pH was measured by preparing pseudo-reaction mixtures using unlabeled phosphorylcholine and reading the $\mathrm{pH}$ after $5 \mathrm{~min}$ incubation at $37^{\circ}$ on a Corning model $12 \mathrm{pH}$ meter. $\AA$, sample 1 ; $\bullet$, sample 2 .

Table 1. Effect of temperature, storage, and oxygen on enzyme activity

\begin{tabular}{cccccc}
\hline & \multicolumn{5}{c}{ Activity $^{1}$} \\
\cline { 2 - 5 } Variables & $\begin{array}{c}\text { CDP-choline/ } \\
\text { mg protein }\end{array}$ & $\begin{array}{c}1-\mathrm{hr} \\
\text { homog- } \\
\text { enate }\end{array}$ & $\begin{array}{c}1-\mathrm{hr} \\
\text { tissue }\end{array}$ & $\begin{array}{c}7-\mathrm{hr} \\
\text { tissue }\end{array}$ & $\begin{array}{c}\% \text { of } \\
\text { control }\end{array}$ \\
\hline
\end{tabular}

Temperature

$\begin{array}{rr}4^{\circ} & 0.20 \\ 25^{\circ} & 1.07 \\ 37^{\circ} & 3.32 \\ 49^{\circ} & 5.73 \\ 57^{\circ} & 3.02 \\ 70^{\circ} & 0.04\end{array}$

Day after sample ${ }^{3}$

$\begin{array}{ccccc}\text { Day 0 } & 5.59 & & & \\ \text { Day } 6 & 5.82 & 4.93 & 6.44 & \\ \text { Day } 13 & 6.59 & 5.98 & 7.43 & \\ \text { Oxygen }^{4} & & & & \\ 21 \% & & & & 100 \\ 95 \% & & & & 98 \\ 0 \% & & & & 94\end{array}$

${ }^{1}$ Average of duplicate analyses, differing by less than $5 \%$.

${ }^{2}$ The assay comparing the effect of $\mathrm{O}_{2}$ and $\mathrm{N}_{2}$ on enzymatic activity was performed in Warburg flasks using twice the amount of reactants as usual. The reaction mixtures were preincubated and the reaction carried out under their respective atmospheres. The reaction was stopped by pouring the contents of the flask into a centrifuge tube and boiling for $5 \mathrm{~min}$. The flasks were rinsed with $1.0 \mathrm{ml} \mathrm{H}_{2} \mathrm{O}$ and this washing was added to the tube in the boiling water.

${ }^{3}$ Stored at $-12^{\circ}$.

${ }^{4}$ Standard assay conditions as described in the text, average of duplicate samples.

contained 3 times as much activity as the supernatant obtained after centrifugation at $2,500 \times g$. Addition of boiled precipitate did not enhance the activity in supernatant.

Enzyme activity was determined over a range of CTP concentrations $(0.30-6.0 \mathrm{mM})$, keeping the phosphorylcholine concentration at $5.0 \mathrm{mM}$. Activity reached a maximum at about $3.0 \mathrm{mM}$. The classical Lineweaver-Burk plot (Fig. 2, 
top) gave $\mathrm{V}_{\max }$ of $4.0 \mathrm{nmol} / \mathrm{mg}$ protein $/ 10 \mathrm{~min}$ and a $\mathrm{K}_{\mathrm{m}}$ for CTP of $2.0 \times 10^{-3} \mathrm{M}$. Activity was then determined while keeping the CTP concentration at $6.0 \mathrm{mM}$, as the phosphorylcholine concentration was varied from 0.05 to $5.0 \mathrm{mM}$. The Lineweaver-Burk plot (Fig. 2, bottom) gave a $\mathrm{V}_{\max }=7.14$ $\mathrm{nmol} / \mathrm{mg}$ protein $/ 10 \mathrm{~min}$, and a $\mathrm{K}_{\mathrm{m}}$ for phosphorylcholine of $0.25 \times 10^{-3} \mathrm{M}$

These are kinetic values relative to the concentration of each substrate, since phosphorylcholine cytidyltransferase catalyzes a bisubstrate reaction. Therefore, to find true kinetic values, initial rates of activity were studied as a function of the concentration of phosphorylcholine at several fixed concentrations of CTP, and vice versa as a function of varying concentrations of phosphorylcholine. These data (Figs. 3 and 4) indicate that the $K_{m}$ for either substrate varies slightly with the concentration of the second substrate. Secondary plots of the $1 / \mathrm{v}$ intercepts versus $1 /$ concentration of fixed substrate) yielded the true $V_{\max }$ and $\mathrm{K}_{\mathrm{m}}$ ' for each substrate (Fig. 5). The apparent $\mathrm{K}_{\mathrm{m}}$ (intercept of $1 / \mathrm{v}$ versus $1 / \mathrm{S}$ at several fixed concentrations of the second substrate $)$ of CTP $\left(2.5 \times 10^{-3}\right.$ $M$, Fig. 3) varied little from the $K_{m}{ }^{\prime}\left(2.0 \times 10^{-3} M\right)$ obtained by the second plots of the previous intercepts (Fig. 5). The apparent $\mathrm{K}_{\mathrm{m}}$ of phosphorylcholine $\left(1 \times 10^{-3} \mathrm{M}\right)$ (Fig. 4) was fourfold different than the $K_{m}{ }^{\prime}\left(0.25 \times 10^{-3} \mathrm{M}\right)$ obtained from the secondary plots (Fig. 5). The true $\mathrm{V}_{\max }$ is $10 \mathrm{nmol}$ CDP-choline $/ \mathrm{mg}$ protein $/ 10 \mathrm{~min}$.

\section{DISCUSSION}

The key role of lecithin as the major component of lung surfactant, and its known relationship to respiratory distress syndrome in the human neonate (23), has led to interest in its
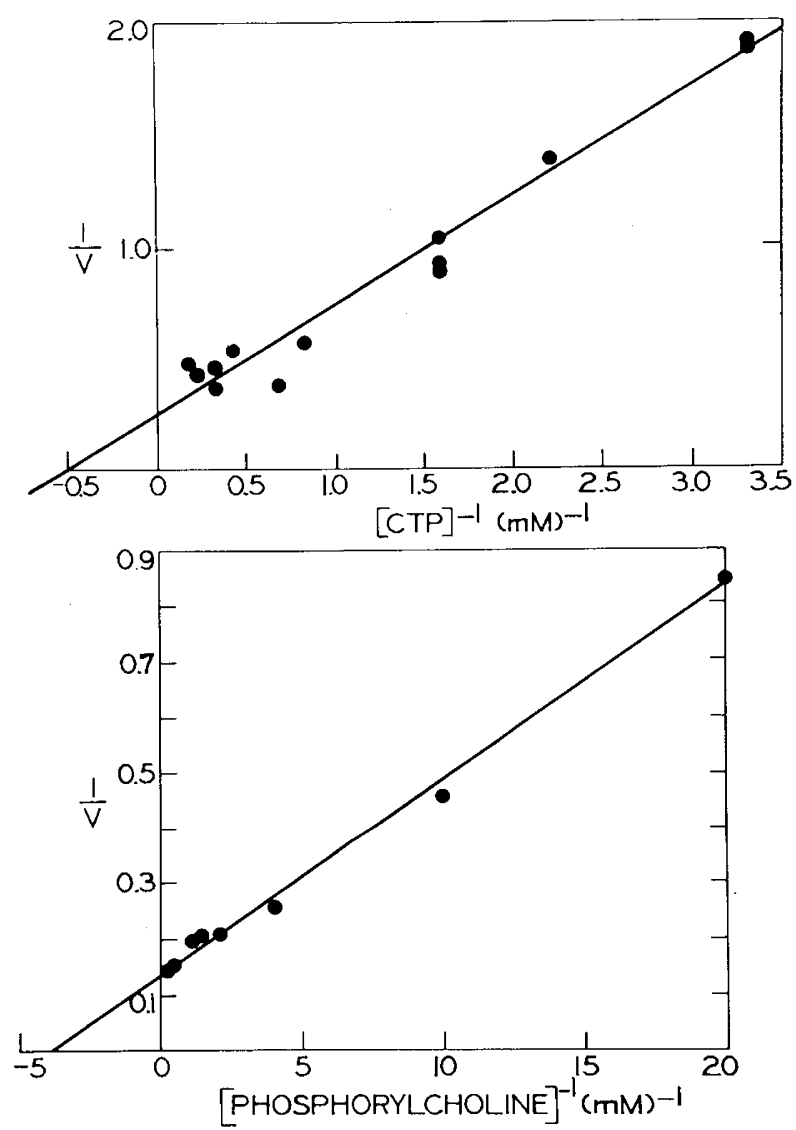

Fig. 2. Effect of substrate concentration on enzyme activity, Lineweaver-Burk plot. The indicated concentrations of CTP were varied with phosphorylcholine constant at $5 \mathrm{mM}$ (top). Phosphorylcholine was varied as indicated with CTP constant at $6 \mathrm{mM}$ (bottom). Velocity is defined as nanomoles per milligram of protein per $10 \mathrm{~min}$.

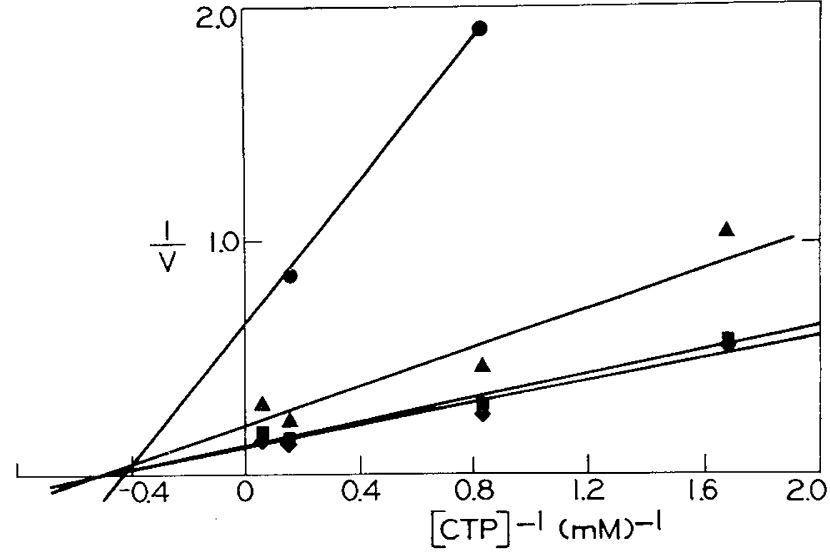

Fig. 3. Kinetic parameters of phosphorylcholine cytidyltransferase. Assay is as described in the text. Initial rates of enzyme activity were determined as a function of variable concentrations of CTP at several fixed concentrations of phosphorylcholine. $\bullet--\bullet, 0.05 \mathrm{mM} ; \bullet--\bullet, 0.5$ $\mathrm{mM} ;--\varpi, 2.5 \mathrm{mM}$; and,$-- 5.0 \mathrm{mM}$.

biosynthesis in lung $(3,12,14,19,27)$. Synthesis by the CDP-choline pathway in lung of experimental animals occurs and recent evidence suggests that the CDP-choline pathway is present in human neonatal lung as well $(12,30,31)$.

Phosphorylcholine cytidyltransferase, the enzyme responsible for the second step in the CDP-choline pathway, is demonstrated for the first time in human neonatal lung. It has been studied previously in detail in rat and guinea pig liver (6, $11,25)$, chicken peripheral nervous tissue (21), and has been noted also in rat heart and calf brain (6) and rat lung (26). The assay is described here for maximal velocity, and is reliable by several criteria: (1) linear with protein concentration, (2) linear for 10-20-min incubation, (3) duplicates within $\pm 2-5 \%$ (4) minimal loss of product through isolation technique or further reactions. Some loss of reaction product occurred because of absorption onto denatured protein, but the effects of this were minimized by using the same amount of homogenate within each series of experiments.

No loss of activity occurred between $1-7 \mathrm{hr}$ under postmortem conditions $\left(4^{\circ}\right)$. The frozen enzyme was stable and even slightly enhanced, as characteristic of the enzyme from other sources (6). Some reports have suggested a three-to fourfold enhanced activity after storage in the cold (25). The $\mathrm{pH}$ optimum of 6.0-6.5 was similar to the liver enzyme of 6.0-7.2 $(2,6)$. Several enzymes of lung are sensitive to oxygen (16). However, oxygen had no apparent effect on human neonatal lung phosphorylcholine cytidyltransferase activity during short reaction periods. Phosphorylcholine cytidyltransferase was found in the soluble and microsomal $(100,000 \times g)$ fractions by others $(2,11,21,25,28)$. The enzyme was not present in the supernatant of the mollusc, but the whole homogenate was not apparently assayed (18). Only one third of the enzyme activity of human lung was in the supernatant. Possibly incomplete cell disruption was obtained with the glass mortar-Teflon pestle homogenization. Other methods of preparing a more soluble form of the enzyme to facilitate purification procedures need investigation.

The $K_{m}$ for CTP $\left(2.0-2.5 \times 10^{-3} \mathrm{M}\right)$ with human lung enzyme is greater than the $0.3 \times 10^{-3} \mathrm{M}$ reported for rat liver $(2,6)$. This discrepancy could be due to the presence of enzymes in the crude human lung homogenate preparation which degrade CTP during the reaction (29). If so, the actual effective CTP concentration in our system might be less than supposed from the added CTP alone. The $\mathrm{K}_{\mathrm{m}}$ for phosphorylcholine $\left(0.25-1.0 \times 10^{-3} \mathrm{M}\right)$ reported here is similar to that of $0.5-1 \times 10^{-3} \mathrm{M}$ reported previously from other tissues (2, 6).

The kinetic constants for human lung phosphorylcholine 


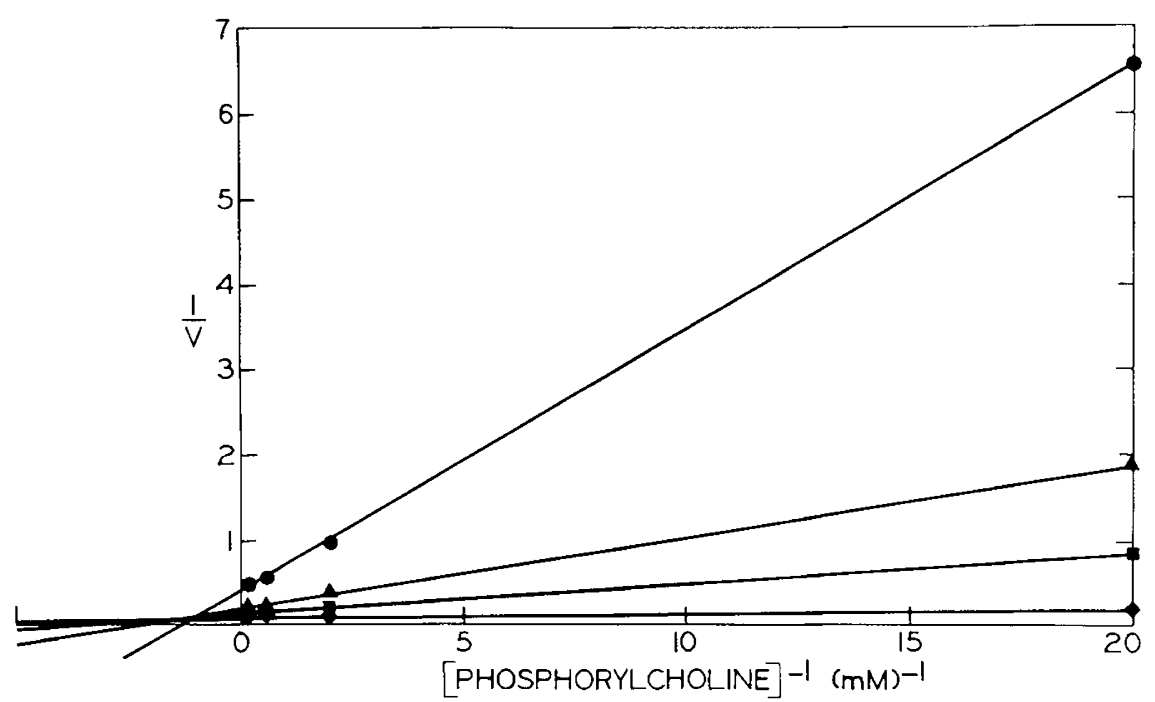

Fig. 4. Kinetic parameters of phosphorylcholine cytidyltransferase. Assay is as described in the text. Initial rates of enzyme activity were determined as a function of variable concentrations of phosphorylcholine at several fixed concentrations of CTP, $\bullet--\bullet, 0.6 \mathrm{mM} ; \bullet--\Delta, 1.2 \mathrm{mM}$; $\bullet-\rightarrow, 6.0 \mathrm{mM} ;--\square, 12.0 \mathrm{mM}$.

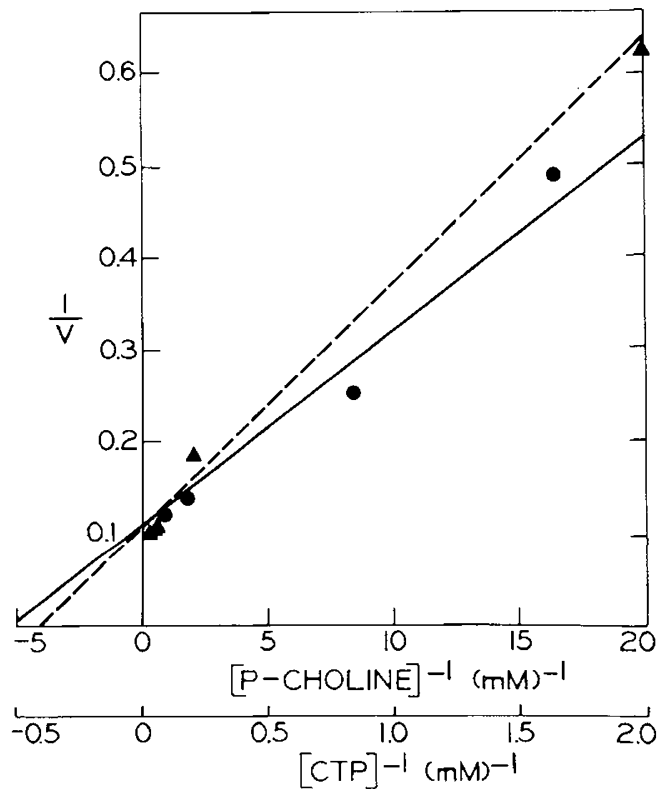

Fig. 5. Kinetic parameters of phosphorylcholine cytidyltransferase. $\mathrm{V}_{\max }$ is plotted versus $1 / \mathrm{s}$. A-_-_, phosphorylcholine; •--•, cytidyltransferase.

cytidyltransferase were determined in the presence of varying substrate concentrations, which has not been done for the enzyme previously from any source. The nearness of the $\mathrm{K}_{\mathrm{m}}$ CTP $\left(2.0 \times 10^{-3} \mathrm{M}\right)$ makes it doubtful that previous binding of phosphorylcholine to the enzyme affects subsequent binding of CTP. In contrast, the $\mathrm{K}_{\mathrm{m}}{ }^{\prime} \mathrm{P}$-choline $\left(0.25 \times 10^{-3}\right.$ $\mathrm{M})$ is enough different from the $\mathrm{K}_{\mathrm{m}} \mathrm{P}$-choline $\left(1.0 \times 10^{-3} \mathrm{M}\right)$ to suggest that previous binding of CTP to the enzyme aids the subsequent binding of phosphorylcholine. However, these are small differences in kinetic constants in a crude homogenate system. The significance of these findings will depend on further purification and characterization of phosphorylcholine cytidyltransferase from human neonatal lung.

\section{SUMMARY}

The enzyme, phosphorylcholine cytidyltransferase, was studied for the first time in homogenates of human neonatal lung. The effect on enzyme activity of protein concentration, $\mathrm{pH}$, frozen homogenate, and frozen whole tissue aging, postmortem aging before obtaining tissue, and oxygen was determined. The kinetic constant for each substrate over varying concentrations of the second substrate was determined and suggested a possible allosteric effect of previous binding of CTP to the enzyme on the subsequent binding of phosphorylcholine. The significance of these findings depends on the separation and isolation of the specific cell type responsible for lecithin biosynthesis and/or further purification of phosphorylcholine cytidyltransferase from human neonatal lung preparations.

\section{REFERENCES AND NOTES}

1. Adams, F. H., Fujiwara, T., Emmanouilides, G., and Scudder, A.: Surface properties and lipids from lungs of infants with hyaline membrane disease. J. Pediat., 66: 357 (1965).

2. Ansell, G. B., and Chojnacki, T.: CTP: Base phosphate cytidyltransferases: CTP-choline phosphate cytidyltransferase. Methods Enzymol., 13: 121 (1969).

3. Artom, C.: Enzymes for the synthesis of lecithins from choline in tissues of developing rats. Fed. Proc., 27: 457 (1968).

4. Avery, M. E., and Mead, J.: Surface properties in relation to atelectasis and hyaline membrane disease. Amer. J. Dis. Child., 97: 517 (1959).

5. Bjornstad, P., and Bremer, J.: In vivo studies on pathways for the biosynthesis of lecithin in the rat. J. Lipid Res. 7: 38 (1966).

6. Borkenhagen, L. F., and Kennedy, E. P.: The enzymatic synthesis of cytidine diphosphate choline. J. Biol. Chem., 227: 951 (1957).

7. Bremer, J., and Greenberg, D. M.: Methyl transferring enzyme system of microsomes in the biosynthesis of lecithin (phosphatidylcholine). Biochim. Biophys. Acta, 46: 205 (1961).

8. Brown, E. S.: Isolation and assay of dipalmityl lecithin in lung extracts. Amer. J. Physiol., 207: 402 (1964).

9. Brumley, G. W., Hodson, W. A., and Avery, M. E.: Lung phospholipids and surface tension correlations in infants with and without hyaline membrane disease and in adults. Pediatrics, 40: 13 (1967)

10. Chu, J., Clements, J. A., Cotton, E. K., Klaus, M. H., Sweet, A. Y., Thomas, M. A., and Tooley, W. H.: The pulmonary hypoperfusion syndrome. Pediatrics, 35: 733 (1965).

11. Fiscus, W. G., and Schneider, W. C.: The role of phospholipids in stimulating phosphorylcholine cytidyltransferase activity. J. Biol. Chem., 241: 3324 (1966).

12. Gluck, L., Kulovich, M. V., Eidelman, A. I., Cordero, I., and Khazin, A. F.: Biochemical development of surface activity in mammalian lung. IV. Pulmonary lecithin synthesis in the human fetus and newborn and etiology of the respiratory distress syndrome. Pediat. Res., 6: 81 (1972).

13. Gluck, L., Motoyama, E. K., Smits, H. L., and Kulovich, M. V.: The biochemical development of surface activity in mammalian lung. I. The surface-active phospholipids; the separation and distribution of surface-active lecithin in the lung of the developing rabbit fetus. Pediat. Res., $l: 237$ (1967).

14. Gluck, L., Sribney, M., and Kulovich, M. J.: The biochemical development of surface activity in mammalian lung. II. The 
biosynthesis of phospholipids in the lung of the developing rabbit fetus and newborn. Pediat. Res., 1: 247 (1967).

15. Gruenwald, P., Johnson R. P., Husted, R. F., and Clements, J. A.: Correlation of mechanical properties of infant lungs with surface activity of extracts. Proc. Soc. Exp. Biol. Med., 109: 369 (1962).

16. Haugaard, N.: Cellular mechanisms of oxygen toxicity. Physiol. Rev., 48: 312 (1968)

17. Kennedy, E. P., and Weiss, S. B.: The function of cytidine coenzymes in the biosynthesis of phospholipids. J. Biol. Chem., 222: 193 (1956).

18. Liang, C. R., Segura, M., and Strickland, K. P.: Phospholipid metabolism in the molluscs. II. Activities of choline kinase, ethanolamine kinase, and CTP: Phosphorylethanolamine cytidyltransferase in the mollusc, Helix lactea. Canad. J. Biochem., 48 : $580(1970)$.

19. Morgan, T. E.: Isolation and characterization of lipid $N$-methyltransferase from dog lung. Biochim. Biophys. Acta, 178: 21 (1969).

20. Pattle, R. E., Claireaux, A. E., Davies, P. A., and Cameron, A. H.: Inability to form a lung lining film as a cause of the respiratory distress syndrome in the newborn. Lancet, ii: 469 (1962).

21. Porcellati, G., and Arienti, G.: The cytidine triphosphate: cholinephosphate cytidyltransferase of normal and degenerating peripheral nerve: A study of its activation by phospholipids. Brain Res., 19: 451 (1970)

22. Scarpelli, E. M.: The Surfactant System of the Lung, Chap. 4, p. 53 (Lea \& Febiger, Philadelphia, 1968).

23. Scarpelli, E. M.: Respiratory distress syndrome. In: Surfactant System of the Lung, p. 177 Lea \& Febiger, Philadelphia, 1968.

24. Scarpelli, E. M., Clutario, B. C., and Taylor, F. A.: Preliminary identification of the lung surfactant system. J. Appl. Physiol., 23: 880 (1967)

25. Schneider, W. C.: Intracellular distribution of enzymes. XIII. Enzymatic synthesis of deoxycytidine diphosphate choline and

Copyright @ 1975 International Pediatric Research Foundation, Inc. lecithin in rat liver. J. Biol. Chem., 238: 3572 (1963).

26. Stern, W., and Weinhold, P.: CTP-choline phosphate cytidyltransferase: Changes in the activity and phospholipid requirement during prenatal development of the rat lung. Fed. Proc., 31:453 (1972).

27. Weinhold, P. A.: Biosynthesis of phosphatidylcholine during prenatal development of the rat lung. J. Lipid Res., 9: 262 (1968).

28. Weinhold, P. A., and Villee, C. A.: Phospholipid metabolism in the liver and lung of rats during development. Biochim. Biophys. Acta, 106: 540 (1965).

29. Wilgrain, G. F., and Kennedy, E. P.: Intracellular distribution of some enzymes catalyzing reactions in the biosynthesis of complex lipids. J. Biol. Chem., 238: 2615 (1963).

30. Zachman, R. D.: The enzymes of lecithin biosynthesis in human newborn lungs. I. Choline kinase. Biol. Neonate, 19: 211 (1971).

31. Zachman, R. D.: The enzymes of lecithin biosynthesis in human newborn lungs. III. Phosphorylcholine glyceride transferase. Pediat. Res., 7: 632 (1973).

32. Sigma Chemical Company, St. Louis, Mo.

33. Mallinckrodt Company, Minneapolis, Minn.

34. Tracerlab, Irvine, Calif.

35. The technical assistance of Ms. Agnes Chung and the constructive comments of Drs. E. Burt Olson and Phillip Farrell are acknowledged. Dr. Farrell s especially acknowledged for his help in the design of the kinetic studies.

36. This work was supported in part by grants from the John A. Hartford Foundation and the Public Health Service (HD 05837 and HL-17239).

37. Requests for reprints should be addressed to: R. D. Zachman, M.D., Department of Pediatrics, University of Wisconsin, The Wisconsin Perinatal Center, 720 S. Brooks St., Madison, Wisc. 53715 (USA).

38. Accepted for publication, January $2,1975$. 